\title{
Teaching Trajectories and Students' Understanding of Difficult Concepts in Biology in Obio/Akpor Local Government Area in Rivers State
}

\author{
Abosede Anthonia Olufemi Mumuni ${ }^{1}$, John Worlu Dike ${ }^{1} \&$ Azibaolanari Uzoma-Nwogu, ${ }^{1, *}$ \\ ${ }^{1}$ Department of Curriculum Studies and Educational Technology,Faculty of Education, University of Port Harcourt, \\ P.M.B 5323, Choba, Rivers State, Nigeria \\ *Correspondence: Department of Curriculum Studies and Educational Technology, Faculty of Education, University \\ of Port Harcourt, P.M.B 5323 Choba, Rivers State, Nigeria. Tel: 234-803-710-5152. E-mail: \\ nwoguzoazis@yahoo.com
}

Received: November 18, 2016

Accepted: Decmeber 15, 2016 Online Published: January 17, 2017

doi:10.5430/wje.v7n1p44

URL: http://dx.doi.org/10.5430/wje.v7n1p44

\begin{abstract}
This study investigated the effects of teaching trajectories on students' understanding of difficult concepts in Biology. Two research questions and two null hypotheses guided the study which was carried out in Obio/Akpor Local Government Area of Rivers State. Two public coeducational schools out of thirteen drawn through purposive sampling techniques were used. The instrument for data collection, the Students' Photosynthesis Achievement Test (SPAT) was validated and its reliability coefficient was 0.78 . Three intact streams of SS 1 classes in the two schools assigned to book-ending, guided discussion and jigsaws groups were used. The sample consisted of two hundred and thirteen SS 1 Biology students. Mean and standard deviations were used to answer the two research questions while paired t-tests and ANCOVA were used to answer the two hypotheses at 0.05 level of significance. The study revealed that though the three instructional strategies of book-ending, jig-saws and guided discussion enhanced students' understanding of difficult concept in Biology as shown by the improved achievement scores, the jig-saw strategy was the best. It also revealed that there was a significant difference between the achievement of males and females in favour of females in the three groups. Recommendations made based on the findings of the study included that teachers adopt the jigsaw strategy to enhance students' understanding of difficult concepts in Biology.
\end{abstract}

Keywords: trajectories; understanding; difficult concepts; book-ending; guided discussion; jigsaw

\section{Introduction}

Science and technology have changed the face of history for many nations of the world today, ultimately giving rise to the current globalization and subsequent categorization into highly developed, developing or under-developed countries. The notably visible effects of science and technology have therefore galvanized countries to invest enormous national resources for the establishment and nurture of a stable, well-supported science and technology education (Akpan, 2012). Nigeria too, has keyed in to improve the teaching of science in schools in order to reap a huge scientific and technological harvest of growth and development in the near future, as can be distilled from the goals of science education clearly specified and stated in the National Policy of Education (FRN, 2004; 19) as follows:

- Cultivation of an inquiring, rational and knowing mind for the conduct of a good life and democracy;

- Production of scientists for national development;

- Servicing of studies in technology and the course of technological development and

- Provision of knowledge and understanding of the complexity of the physical world, the forms and the conduct of life.

The teaching of science is to cut across all levels of education, which is why science is one of the curricula at the primary, secondary and tertiary levels of education. The implication is that science is for all and everybody. It goes without saying, then, that a strong foundation in primary science is a pre-requisite for whatever science is to be studied at the other levels. The corollary to this is that for Nigeria or any nation for that matter, to experience the desired 
technological growth and advancement, there must be a strong stimulation and growth in the teaching and learning of science at all levels.

The National Science Education Standards (NRC, 1999; 20) lends credence to this, advocating that everyone, without exception is to learn science and acquire sustainable levels of scientific literacy.

The acquisition of scientific literacy is therefore dependent on a solid foundation beginning from the early years of schooling. Scientific literacy, in its simplest form, is the ability of an individual to utilize scientific knowledge in real-world situations and is of utmost essence in today's world giving that more and more jobs require that people think critically, solve problems and use technology effectively. Akpan $(2012 ; 79)$ surmises that the tools with which to excel in global competiveness are embedded in the ability to acquire science skills that will enable creativity and inventiveness throughout life. This is the impetus underlying the strong advocacy for achieving wider scientific literacy through science teaching and learning because it is a clear indication that a scientifically-literate citizenry is needed for successful competition in the global market-place.

Ezeliora (2008) however opines that Nigeria is yet to be scientifically-literate since her educational system has not achieved the educational objective of science which is "to reorient the entire society towards scientific thinking and adapt the existing ones to improve societal well-being and security". She suggests that achieving scientific literacy through the Universal Basic Education (UBE) programme would require such machineries as the curricula, teacher education, funding and implementation issues to be properly put in focus. This insinuates that there are underlying constraints on science teaching and learning not just at the UBE level, but also all other levels of the educational system. Akpan (2012) has highlighted these problems as including overcrowded classrooms, lack of textual materials, shortage of qualified teachers, to mention but a few. Science Teachers' Association of Nigeria Position Paper No. 4 as stated in Okebukola (2002) has however classified these gnawing problems into the following categories, viz:

- Government-related factors

- Examination body-related factors

- Teacher-related factors

- Student-related factors

- School-related factors and

- Home-related factors

Besieged with the above issues, it is no wonder that extant literature is replete with reports of the persistent and consistent yet deplorably low academic performance of students in science. Ogunleye (2011) has specifically stated that "there has been a steady increase in the failure rates for Physics, Chemistry and Biology over the years" as shown in Table 1 below:

Table 1. Performance for Candidates in SSCE May/June in Some Science Subjects (2001 - 2006)

\begin{tabular}{llllllc}
\hline Year & $\begin{array}{c}\text { No. Sat for } \\
\text { Chemistry }\end{array}$ & $\begin{array}{c}\text { \% in Grade } \\
\mathbf{1 - 6}\end{array}$ & $\begin{array}{c}\text { No. Sate in } \\
\text { Biology }\end{array}$ & $\begin{array}{c}\text { \% in Grade } \\
\mathbf{1 - 6}\end{array}$ & $\begin{array}{c}\text { No sat in } \\
\text { Physics }\end{array}$ & $\begin{array}{c}\text { \% in Grade } \\
\mathbf{1 - 6}\end{array}$ \\
\hline 2001 & 301,740 & 36.25 & 995,345 & 23.25 & 287,993 & 34.41 \\
2002 & 309,112 & 34.89 & $1,047,235$ & 31.39 & 298,059 & 47.66 \\
2003 & 320,388 & 49.66 & $1,005,553$ & 42.22 & 305,501 & 46.90 \\
2004 & 142,480 & 40.03 & $1,005,894$ & 29.68 & 326,091 & 48.83 \\
2005 & 359,296 & 51.33 & $1,051,557$ & 35.74 & 345,640 & 41.70 \\
2006 & 393,206 & 43.34 & $1,137,181$ & 49.23 & 379,365 & 58.29 \\
\hline
\end{tabular}

Source: The West African Examination Council (Test Development Centre)

Adapted from: Ogunleye, A. O. (2011)

The case of Biology is rather pathetic seeing as more students enroll for it yet the performance is still surprisingly poor.

Biology, the study of living things, is one of the core science subjects (others are Physics and Chemistry) studied in secondary schools. As a science subject, it contributes immensely to the scientific and technological development of the nation being a fundamental pre-requisite for other advanced fields such as medicine, forestry, agriculture, pharmacy, nursing, biotechnology, nutrigenomics, neuroparasitology, synthetic biology, quantitative biology, etc. and also important in the manufacturing and processing industries (Nwagbo and Okoro, 2012; Dvorsky, 2013 and Okoli 
and Okoli, 2014). These endeavours give individuals the leverage to cope with life and living in this technological age and this lends credence to the view that one of the well accepted general goals of science education is to prepare individuals for improving their own lives and coping with an increasingly technological world (Osisioma, 2012). In line with this goal, the main objectives of the Biology curriculum (FME, 2009) as derived from the National Policy on Education are to ensure that students are thoroughly prepared for the acquisition of:

- adequate laboratory and field skills in Biology;

- meaningful and relevant knowledge in Biology;

- ability to apply scientific knowledge to everyday life in matters of personal and community health and agriculture and

- reasonable and functional scientific attitude.

Like the curricula of other science subjects (chemistry and physics, for example), the objectives outlined above are quite laudable, but the question that readily distils is: Why then are students performing so poorly in science generally and Biology, particularly? Among the many reasons adduced for students' poor performance in science subjects, poor instructional methodologies and students' difficulty in understanding science concepts stand out (Ogu, 2008; Egbunonu and Ugbaja, 2011; Çimer, 2012, Abimbola, 2015, and Jimoh, 2015). In Biology, several topics and concepts such as genetics, respiration, cell division, photosynthesis, evolution, ecology, hormonal regulation, and nervous co-ordination, among others have been tagged difficult because students are not finding them easy to learn due to the following reasons: overloaded curriculum, abstract nature of some concepts, inadequate time to think through and process learning and inability of teachers to engage students in meaningful learning (Koba and Tweed, 1999; Çimer, 2012 and Okoli and Okoli, 2012). Though reports have called for the use of methods and approaches which are activity-based, didactic teaching methods are still prevalent in many science classrooms in Nigeria. Okebukola (2002) has therefore called for new trajectories in science teaching with due consideration for the dynamics of the growth of science which is inextricably intertwined with life and living in these modern times. There is a consensus that there is no best method but that a combination of improved strategies and approaches will definitely lead to the achievement of defined goals and objectives.

In this study, teaching trajectories are used to mean strategies which are activity-based, involving developmental or progressive steps used by teachers for classroom action and interaction as adapted from Clements and Sarama (2015). The three strategies used in this study include 'book-ending' the lecturers, discussion and jigsaw group.

Book-ending the lecture strategy (BES) is a teaching strategy which is a shift away from the well-known and used lecture method. Allen and Tanner (2015) describe it as "a relatively easy departure point for instructors who want to preserve the lecture-based approach as the central classroom instructional feature" but in this case, suffused and interjected with effective questions. These questions which may be probing and driving but directed at critical thinking for better conceptual understanding have an expanded scope requiring answers beyond the usual stereotypic 'yes-no'. The advantages of this strategy are enormous especially when the questions are focused. This active, intellectual engagement which is an array of questions progressing from the lower order to higher order has the immense advantage of providing a framework for students' active participation, helping students organize and summarize, learn to make explanations and also find ways to fit new information into existing knowledge frame works (Felder, 1997; Gbamanja, 1999; Krajcik, et al, 2003, Nwafor and Nwogu, 2014 and).

The second strategy used in the study was the Guided Discussion Strategy (GDS). As an active-learning and student-centred strategy, it involves the active participation of students. Studies reveal that guided discussion improves learning by enhancing student understanding, helps develop individual thinking, broadens students' perspectives, highlight opposing viewpoints, reinforces knowledge, helps negotiation of meaning and sharing and understanding of issues (Ngeow, 2003 and Blount and Napolitano, 2014).

The third active-learning strategy used is the Jigsaw Strategy (JSS), which adopts the division of labour procedural style that requires rotation of roles by students, thereby developing their skills in all areas (Joyce et al, 2009). It is a form of co-operative learning which enhances student achievement as they gain in-depth knowledge of concepts and subject-matter from the roles they handle. Students are put into 'home' and 'expert' groups. Portions of the materials to be taught are assigned to different members of the home groups who now seek out their expert groups where they engage in intense study of that their own portion. They return, afterwards, to their home groups and peer-tutor on their portions, sequentially (Marzano, 2007 and Odagboyi, et al, 2015).

The above strategies, though not entirely novel include a 'pot pourri' of techniques with theoretical learnings on constructivism proposed by Jean Piaget and Lev Vygotsky aimed at enhancing students' conceptual understanding 
(Okebukola, 2002). With the constant evolution of knowledge, it behooves on teachers to learn to facilitate meaning and deeper understanding of concepts for learners by their own practices (NRC, 1999). The corollary to this is that the instructional frameworks used by teachers ought to be flexible enough, taking cognizance of students' prior knowledge for the learners' needs to be met. In this vein, Achuonye (2010) opined that the choice of instructional method should be guided by the skills we expect the students to acquire. These skills which include critical thinking should be continually improved upon so that they become a veritable utility in the after-school years' endeavours.

It is, therefore, against this background of poor instructional methodology and deplorable performance of students in science that this study is focused on teaching trajectories and students' understanding of difficult concepts in Biology. The problem of this study is to investigate the effectiveness of the active-learning strategies of book-ending, guided discussion and jigsaw on students' understanding of difficult concepts in Biology?

\section{Purpose of the Study}

Specifically, this study sought to determine the effect of book-ending, group discussion and jig-saw strategies on students' understanding of difficult concepts in Biology.

\subsection{Research Questions}

What is the effect of book-ending (BES), guided discussion (GDS) and jig-saw (JSS) on students' understanding of difficult concepts in Biology using their mean achievement scores?

What is the effect of book-ending (BES), guided discussion (GDS) and jigsaw strategies (JSS) on male and female students' understanding of difficult concepts in Biology using their mean achievement scores?

\subsection{Hypotheses}

The two null hypotheses of the study were tested at 0.05 significance level

$\mathrm{Ho}_{1}$ : There is no significant effect of BES, GDS and JSS on students' understanding of difficult concepts in Biology.

$\mathrm{Ho}_{1}$ : These is no significant difference in the effect of BES, GDS and JSS on male and female students' understanding of difficult concepts in Biology.

\section{Methods and Procedure}

\subsection{Design}

The Quasi-experimental design type used for the study was the pretest-posttest with non-equivalence in the groups which included control. The three groups used for the study were non-equivalent because intact classes were involved in order not to disrupt the school time-table of activities. The design is represented as follows:

$$
\begin{aligned}
& \mathrm{y}_{\mathrm{b}} \mathrm{x}_{1} \mathrm{y}_{\mathrm{a}} \\
& \mathrm{y}_{\mathrm{b}} \mathrm{x}_{2} \mathrm{y}_{\mathrm{a}} \\
& \mathrm{y}_{\mathrm{b}} \mathrm{x}_{3} \mathrm{y}_{\mathrm{a}}
\end{aligned}
$$

where:

$$
\begin{aligned}
& \mathrm{y}_{\mathrm{b}}=\text { pretest } \\
& \mathrm{y}_{\mathrm{a}}=\text { posttest } \\
& \mathrm{x}_{1}=\text { book-ending strategy group (BES) } \\
& \mathrm{x}_{2}=\text { guided discussion (GDS) } \\
& \mathrm{x}_{3}=\text { jig-saw strategy group (JSS) }
\end{aligned}
$$

\subsection{Sample and Sampling Technique}

The population for the study consisted of all the senior secondary school students in their first year (SS1) in the thirteen public co-educational schools of Obio/Akpor Local Government Area in Rivers State. The sample consisted of two hundred and thirteen (213) SS 1 students out of which one hundred and thirty-five (135) were females and seventy-eight (78) were males from two (2) public co-educational secondary schools in Obio/Akpor L.G.A. These schools were specifically selected because they had more than three arms of SS 1. The instrument used for data collection was a self-styled short twenty-item essay- type Students' Photosynthesis Achievement Test (SPAT) based 
on concepts from one topic which was photosynthesis.

The instrument was validated by an expert in Measurement and Evaluation and two experienced senior Biology teachers. The reliability was determined after a test-retest using Cronbach alpha as 0.78 reliability coefficient.

\subsection{Administration of the Instrument}

The teachers of the classes were introduced to and given the instructional packages to study and areas of clarification and explanation were properly addressed. These were the book-ending, guided discussion and jig-saws strategies. Teachers were encouraged to use the strategies to teach two other topics before employing it in the teaching of photosynthesis. Prior to their use, the pre-test consisting of twenty items requiring short explanations and descriptions were administered to the three groups in each of the two schools.

In the book-ending strategy group, students were not split into smaller groups.

In the GDS and JSS strategy groups, the classes were divided into four sub-groups each. The ability of students in each group to effectively interact and work with others in providing and acquiring information on the concepts through discussion and questions as well as book and internet search were stimulated and exploited by the teachers after using two topic other than photosynthesis.

\subsection{Data Collection}

After treatment with the instructional packages, the pre-test which was now scrambled was administered as the post-test. The pretest and post-test scores were derived after marking using a rubric.

These scores were afterwards analyzed to obtain the mean, standard deviation, t-test and ANCOVA in order to answer the research questions and also test the hypotheses for significance.

\subsection{Data Analysis}

The data was analyzed using mean, Standard Deviations (SD) and Analysis of Covariance (ANCOVA). The mean scores of students in the three groups (BES, GDS and JSS) were calculated. The ANCOVA was used to test the two hypotheses. The pretest scores served as covariates for adjustment of initial differences between and within the groups.

\section{Results}

The mean and standard deviation values of the pre-test and posttest scores of students in the three groups of the two schools are shown in Table 2.

\subsection{Research Question 1}

What is the effect of book ending (BES), guided discussion (GDS) and jigsaw (JSS) on students' understanding of difficult concepts in Biology using mean achievement scores?

Table 2. Mean and Standard Deviation of Achievement Scores (Pretest and Posttest)

\begin{tabular}{lllcc}
\hline Experimental groups & Pre-test & Post-test & Mean achievement gain & N \\
\hline BES & & & & \\
$\quad$ Mean & 22.84 & 27.52 & 4.69 & 61 \\
$\quad$ SD & 13.74 & 15.75 & & \\
GDS & & & 10.05 & 70 \\
$\quad$ Mean & 21.81 & 32.31 & & \\
$\quad$ SD & 12.44 & 13.93 & 18.97 & 82 \\
JSS & & & & \\
$\quad$ Mean & 21.66 & 40.63 & & \\
$\quad$ SD & 12.37 & 13.15 & & \\
\hline
\end{tabular}

The result presented in Table 2 shows that the post-test mean scores of the three groups (BES, GDS and JSS) are 27.52, 32.31 and 40.63, respectively. Their standard deviations in that order are: 15.75, 13.93 and 13.15. Conclusively, the mean score of the JSS group is higher than those of BES and GDS groups. The mean achievement gains of the three 
groups are 4.69, 10.05 and 18.97, respectively. Though all three groups show enhanced achievement, JSS is highest while BES is lowest.

\subsection{Hypothesis 1}

There is no significant effect of BES, GDS and JSS on students' understanding of difficult concept (photosynthesis) in Biology based on their achievement scores.

The results in table 4 show that there is a significant effect of BES, GDS and JSS on students' understanding of difficult concepts in Biology. However,

The effect is greater with JSS.

\subsection{Research Question 2}

What is the effect of the three trajectories (BES, GDS, and JSS) on male and female students' understanding of difficult concepts in Biology?

Table 4 shows the post-test mean score and standard deviation of male and female students.

Table 3. Mean and Standard Deviation of Male and Female Students' Post-Test Achievement Scores

\begin{tabular}{lllll}
\hline $\begin{array}{l}\text { Experimental } \\
\text { Groups }\end{array}$ & Gender & N & $\begin{array}{l}\text { Mean of } \\
\text { Post-test }\end{array}$ & SD \\
\hline BES & Male & 18 & 28.83 & 17.80 \\
GDS & Female & 43 & 26.97 & 14.96 \\
JSS & Male & 27 & 31.41 & 11.64 \\
& Female & 43 & 32.88 & 15.31 \\
& Male & 33 & 37.48 & 13.17 \\
Total & Female & 49 & 42.76 & 12.84 \\
\hline
\end{tabular}

Table 3 above shows the post-test mean scores of male and female students in the three groups (BES, GDS, and JSS) as $28.83,31.41$ and 37.48 for males and 26.97, 32.88 and 42.76 for females, respectively. The females show higher mean scores than the males in the GDS and JSS groups, with the highest scores being that of the JSS group. In answering research question 2, the results show a high effect of the JSS on female students' understanding of difficult concepts in Biology.

4. 4 Hypothesis 2

There is no significant difference in the effect of BES, GDS and JSS on male and female students' understanding of difficult concepts (photosynthesis) in Biology based on their mean achievement scores.

This hypothesis was tested using the Analysis of Covariance as shown in the summary in Table 4.

Table 4. Summary of Analysis of Covariance (ANCOVA) of Students' Academic Achievement Scores Using the Three Trajectories (BES, GDS and JSS) and Gender

\begin{tabular}{llllll}
\hline Source & $\begin{array}{c}\text { Type III Sum of } \\
\text { Squares }\end{array}$ & df & Mean square & F & Significance \\
\hline Corrected model & 42129.412 & 6 & 7021.569 & 221.811 & .000 \\
Intercept & 6233.921 & 1 & 6233.921 & 196.929 & .000 \\
Pretest scores & 35140.642 & 1 & 35140.642 & $1.110 \mathrm{E} 3$ & .000 \\
Group & 6167.703 & 2 & 3083.852 & 97.419 & .000 \\
Gender & 128.035 & 1 & 128.035 & 4.045 & .046 \\
Group * Gender & 201.836 & 2 & 100.918 & 3.188 & .043 \\
Error & 6521.076 & 206 & 31.656 & & \\
Total & 296991.000 & 213 & & & \\
Correct total & 48650.488 & 212 & & & \\
\hline
\end{tabular}


The results in Table 4 show significance for Group, Gender and Group * Gender at 2, 1 and 2 degrees of freedom, respectively. Their critical values are 3.04, 3.89 and 3.04 as against the calculated values of 97.42, 4.05 and 3.19, respectively and are higher than 0.05 which is the chosen level of probability. This is an indication that there is difference between the effect of BES, GDS and JSS on male and female students' understanding of difficult concepts in Biology. This difference is in favour of females. It also corroborated the t-test results for testing null hypothesis 1 $\left(\mathrm{Ho}_{1}\right)$. Since the calculated values are higher than the critical values, the null hypothesis is rejected. This is an indication that there is a significant effect of the three trajectories (BES, GDS and JSS) on students' understanding of difficult concepts in Biology and also that gender-wise, there is a higher significant effect on females than males as graphically presented in Fig. 1. In other words, the JSS was the most effective in enhancing students' understanding of difficult concepts in Biology with the females outperforming the males.

\section{Estimated Marginal Means of PosttestScores}

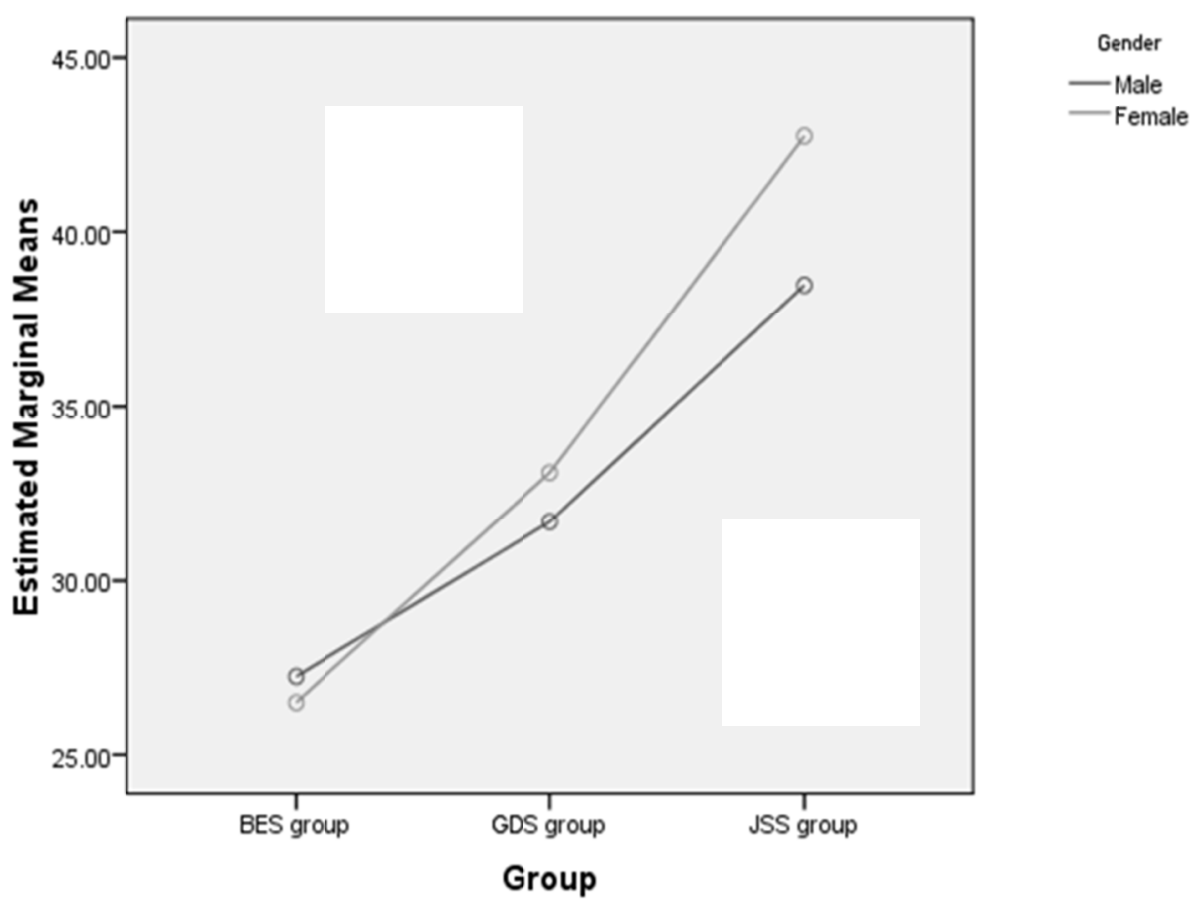

Figure 1. Plot Showing Achievement of Male and Female Students

\section{Discussion}

The study revealed that there was significant effect of the three trajectories (BES, GDS and JSS) on students' understanding of difficult concepts in Biology as observed from the mean of their post-test achievement scores.

Also, the observed and calculated significant effect of the three trajectories (BES, GDS and JSS) on students' understanding of difficult concepts using their mean achievement scores was highest with the JSS group.

Female students in the GDS and JSS groups outperformed their male counterparts as shown by their achievement scores.

Thus, the findings in this study have reveal that effective instructional strategies play a very important role in the academic performance of students especially in science subjects. This is in line with the views of Okebukola (2002), Achuonye (2010) and Odagboyi, Otuka \& Uzoechi (2015) that the reason students perform poorly is because of the ineffectiveness of the way science is taught and learned. Also, studies by Goçer (2010) and Adams (2013) support the view that the jigsaw strategy was effective in enhancing students' academic achievements. The strategies used in this study are co-operative strategies and are a far cry from the conventional method of teaching which does not enhance understanding of concepts but encourages memorization and recalling of facts. Nwagbo and Okoro (2012) also agree that cooperative strategies like these are effective in enhancing the learning of Biology as shown by their performance 
in the achievement tests. The jig-saw strategy (JSS), particularly helps develop many skills in students apart from enhancing their conceptual understanding (Marzano, 2007; Joyce, Weil \& Calhoun, 2009). Slish (2005) and Carpenter (2006) are however not in favour of this argument.

With regard to gender performance, the study by Nwagbo and Okoro (2012) does not agree that females outperformed males, while that of Okoli and Okoli (2014) concluded that gender influence on students' achievement in difficult biology concepts studied was not significant. Further studies however need to be carried out to confirm these results.

\section{Conclusions and Recommendations}

The conclusions made from this study include

a.) That Jigsaw strategy was the most effective.

b.) It also established that the females outperformed the males in their understanding of difficult Biology concepts.

Based on the findings above, it is recommended that Biology teachers should adopt and incorporate the jigsaw strategy in their teaching especially when the topics include difficult concepts and the Ministry of Education should organize seminars and workshops through which serving and pre-service teachers can be trained to learn more about innovative teaching strategies including the (jigsaw strategy) in order to enhance students' academic achievement as well as other skills. Also, teachers should make personal efforts to develop and improve their teaching methods by learning more about the jigsaw strategy in order to incorporate them in their teaching.

\section{References}

Abimbola, I. O. (2015). Teachers' perceptions of important and difficult biology contents. Retrieved 2/6/15, from www.unilorin.edu.ng/publications/abimbola/TEACHERS.htm

Achuonye, K. A. (2010). Stimulating higher order thinking skills in Nigerian students. Journal of Science Teachers' Association of Nigeria (JSTAN), 45(1 \& 2), 85-91.

Adams, F. H. (2013). Using jigsaw technique as an effective way of promoting co-operative learning among primary six pupils in Fijai. International Journal of Education and Practice, 1(6), 64-74.

Agusiobo, W. W. (2002). Constraints to effective implementation of senior secondary schools' physics curriculum in Orumba South LGA. Journal of Technical Education Research and Development (JOTERD).

Akpan, B. B. (2012). Science education in Nigeria. In: Education in Nigeria: From the beginning to the future. Lagos: Foremost Educational Services Ltd.

Allen, D., \& Tanner, K. (2005). Infusing active learning into the large-enrolment biology class: Seven strategies, from the simple to complex. Retrieved 2/6/15, from: www.ncbi.nlm.nihign/pubmed/16344858

Blount, J. M., \& Napoitano, R. (2014). Leading classroom discussion. Retrieved: 5/8/15, from www.celt.iastate.edu/teaching-resources/classrom-practice/teaching-techinques/leading-classrooms-discusion

Carpenter, J. M. (2006). Effective teaching methods for large classes. Journal of family and consumer sciences education, 24, 13-23.

Çimer, A. (2012). What makes Biology learning difficult and effective: Students'views. Retrieved 2/6/15 from http://www.academicjournals.org/ERR

Clements, D., \& Sarama, J. (2015). What are 'Learning Trajectories" and how do they help? Retrieved 22/6/15, from www.mheonline.com/marketing_img/ece_math

Dvorsky, G. (2013). Emerging scientific fields that everyone should know about. Retrieved 29/6/15, from io9.com/5987296/11-emerging-scientific-fields

Egbunonu, R. N., \& Ugbaja, J. N. (2011). Biology teachers' perception of the factors affecting the effective implementation of the Biology curriculum: The way forward for educational reform. $52^{\text {nd }}$ Annual Conference Proceedings of Science Teachers' Association of Nigeria. Pp. 235-241.

Ezeliora, B. (2008). Achieving scientific literacy by the $21^{\text {st }}$ century, Agenda for Universal Basic Education. In, Education for Millennium Development. Essays in honour of Prof. Michael Omolewa. Ed by: Marcie Boucouvalas and Rashid Aderinoye. Ibadan: Spectrum Books Ltd.

Federal Ministry of Education (2009). Biology Curriculum for senior secondary schools. Abuja: NERDC. 
Federal Republic of Nigeria (2014). National Policy on Education.

Felder, R. M. (1997). Beating the numbers game: Effective teaching in large classes. Paper presented at the 1997 ASEE Annual Conference, Milawaukee, WI. Retrieved June 1997 from http://ncsu.edu/felder-pubic/papers/largeclasses.htm

Goçer, A. (2010). A comparative research on the effectively of co-operative learning method and jigsaw technique on teaching literacy genres. Educational Research and Reviews, 5(8), 439-445.

Imhanlahimi, E. O., and Aguele, L. I. (2006). Comparing three instruments for assessing biology teachers' effectiveness in the instructional process in Edo State, Nigeria. Journal of Social Sciences, 13(1), 67-70.

Jimoh, A. T. (2015). Perception of difficult topics in chemistry curriculum by students in Nigerian secondary schools. Ilorin. Journal of Education, 2(3), 18-23.

Joyce, B., Weil M., \& Calhoun, E. (2009). Models of teaching ( $8^{\text {th }}$ ed.). Boston: Pearson Education, Inc.

Koba, S., \& Tweed, A. (2009). Hard-to-teach Biology concepts: A framework to deepen students' understanding. Retrieved 2/6/2015, from www.nsta.org/docs/pB238xweb.pdf

Krajcik, J. S., Cnerziak, C. M., \& Berger, C. F. (2003). Teaching science in elementary and middle school classroom: A project-based approach $\left(2^{\text {nd }}\right.$ ed.). New York: McGraw Hill Higher Education.

Marzano, R. J. (2007). The art and science of teaching: A comprehensive framework for effective instruction. Virginia: Association for Supervision and Curriculum Development.

National Research Council (1999). National science education standards. Washington, D.C: National Academy Press.

Ngeow, K. Y. (2003). Learning through discussion designing tasks for critical inquiry and reflective learning. Retrieved: 5/8/15, from: www.ericdigests.org/2004-1/tasks.htm.

Nwafor, N.H.A., \& Nwogu, U. J. (2014). Dynamics of classroom communication (2 ${ }^{\text {nd }}$ ed.). Port Harcourt: Sambiz Publishing Company

Nwagbo, C. R., \& Okoro, A. U. (2012). Effect of interaction patterns on achievement in Biology among secondary school students. Journal of Science Teachers' Association of Nigeria (JSTAN), 41(1), 23-32.

Odagboyi, I. A., Otuka, J.O.E \& Uzoechi, B. C. (2015). Effect of the jigsaw co-operative learning approach on Biology students' achievement and conceptual change. Journal of the Science Teachers' Association of Nigeria (JSTAN), 50(1), 163-173.

Ogu, M. V. (2008). Problems of physics education in secondary schools in Nigeria. $49^{\text {th }}$ Annual conference proceedings of Science Teachers' Association of Nigeria. Held at Yenagoa, Bayelsa State. Pp. 255-258.

Ogunleye, A. O. (2006). An investigation into the availability and extent of use of resources in the teaching of physics in some Lagos public and private schools. $47^{\text {th }}$ Annual Conference proceedings of Science Teachers' Association of Nigeria pp. 283-290.

Ogunleye, A. O. (2011). The growth and development of science education in Nigeria. In: The growth and development of education in Nigeria. In Ivowi, U.M.O and Ogunleye, A. O. A. (Ed.), book of readings in honour of Prof. P.A.O. Okebukola. Ibadan: HEBN Publishers Plc.

Okebukola, P. A. O. (2002). Beyond the stereotypes to new trajectories in science teaching, being Text of special lecture presented at the $43^{\text {rd }}$ annual conference of Science Teachers' Association of Nigeria (STAN) and Commonwealth Association of Science, Technology and Mathematics Educators, August 19-23, 2002. Ibadan: Science Teachers' Association of Nigeria.

Okoli, J. N., \& Okoli, S. O. (2014). Effect of multiple intelligence-based instructional approach on secondary school students' achievement in the learning of difficult biology concepts. Int. J. of Scientific and Engineering Research, 5(4), 2229-5518.

Osisioma, I. N. (2012). Moving from theory to practice: Applying research on student learning to science education. In: Ivowi, U.M.O. (Ed.), Education in Nigeria: From the beginning to the future. Lagos: Foremost Educational Services Ltd.

Slish, D. (2005). Assessment of the use of the jigsaw method and active learning in non-majors, introductory biology. Bioscience, 31, 4-10. 